\title{
Desiccation and Mortality Dynamics in Seedlings of Different European Beech (Fagus sylvatica L.) Populations under Extreme Drought Conditions
}

OPEN ACCESS

Edited by:

Boris Rewald,

University of Natural Resources and

Life Sciences, Vienna, Austria

Reviewed by:

Christiane Werner,

University of Freiburg, Germany

Frédéric Holzwarth,

Universität Leipzig, Germany

*Correspondence:

Andreas Bolte

andreas.bolte@thuenen.de

Specialty section: This article was submitted to Functional Plant Ecology,

a section of the journal

Frontiers in Plant Science

Received: 28 February 2016

Accepted: 17 May 2016

Published: 14 June 2016

Citation:

Bolte A, Czajkowski T, Cocozza C, Tognetti R, de Miguel M, Pšidová E,

Ditmarová L, Dinca L, Delzon S, Cochard H, Ræbild A, de Luis M, Cvjetkovic B, Heiri C and Müller J

(2016) Desiccation and Mortality

Dynamics in Seedlings of Different

European Beech (Fagus sylvatica L.)

Populations under Extreme Drought

Conditions. Front. Plant Sci. 7:751.

doi: 10.3389/fpls.2016.00751

\begin{abstract}
Andreas Bolte ${ }^{1 *}$, Tomasz Czajkowski ${ }^{1}$, Claudia Cocozza ${ }^{2}$, Roberto Tognetti ${ }^{3,4}$, Marina de Miguel ${ }^{5}$, Eva Pšidová ${ }^{6}$, Lubica Ditmarová ${ }^{6}$, Lucian Dinca ${ }^{7}$, Sylvain Delzon ${ }^{5}$, Hervè Cochard ${ }^{8}$, Anders Ræbild ${ }^{9}$, Martin de Luis ${ }^{10}$, Branislav Cvjetkovic ${ }^{11}$, Caroline Heiri ${ }^{12}$ and Jürgen Müller ${ }^{1}$
\end{abstract}

\begin{abstract}
${ }_{1}^{1}$ Thünen Institute of Forest Ecosystems, Eberswalde, Germany, ${ }^{2}$ Instituto per la Protezione Sostenibile delle Piante (IPSP), Consiglio Nazionale delle Ricerche, Sesto Fiorentino, Italy, ${ }^{3}$ Dipartimento di Bioscienze e Territorio, Università del Molise, Pesche, Italy, ${ }^{4}$ EFI Project Centre on Mountain Forests (MOUNTFOR), Edmund Mach Foundation, San Michele all'Adige, Italy, ${ }^{5}$ BIOGECO, INRA, Université de Bordeaux, Cestas, France, ${ }^{6}$ Institute of Forest Ecology, Slovak Academy of Science, Zvolen, Slovakia, ${ }^{7}$ Marin Dracea National Forest Research-Development Institute, Bucharest, Romania, ${ }^{8}$ PIAF, INRA, Université Clermont Auvergne, Clermont-Ferrand, France, ${ }^{9}$ Department of Geosciences and Natural Resource Management, University of Copenhagen, Frederiksberg C, Denmark, ${ }^{10}$ Grupo de Clima, Agua, Cambio Global y Sistemas Naturales, Departamento de Geografía y Ordenación del Territorio, Facultad de Filosofía y Letras, Instituto de Investigación en Ciencias Ambientales, Universidad de Zaragoza, Zaragoza, Spain, ${ }^{11}$ Faculty of Forestry, University of Banja Luka, Banja Luka, Bosnia and Herzegovina, ${ }^{12}$ Swiss Federal Institute for Forest, Snow and Landscape Research WSL, Birmensdorf, Switzerland
\end{abstract}

European beech (Fagus sylvatica L., hereafter beech), one of the major native tree species in Europe, is known to be drought sensitive. Thus, the identification of critical thresholds of drought impact intensity and duration are of high interest for assessing the adaptive potential of European beech to climate change in its native range. In a common garden experiment with one-year-old seedlings originating from central and marginal origins in six European countries (Denmark, Germany, France, Romania, Bosnia-Herzegovina, and Spain), we applied extreme drought stress and observed desiccation and mortality processes among the different populations and related them to plant water status (predawn water potential, $\Psi_{\mathrm{PD}}$ ) and soil hydraulic traits. For the lethal drought assessment, we used a critical threshold of soil water availability that is reached when 50\% mortality in seedling populations occurs (LD50 SWA $)$. We found significant population differences in LD50swA (10.5-17.8\%), and mortality dynamics that suggest a genetic difference in drought resistance between populations. The LD50 SwA $_{\text {values }}$ correlate significantly with the mean growing season precipitation at population origins, but not with the geographic margins of beech range. Thus, beech range marginality may be more due to climatic conditions than to geographic range. The outcome of this study suggests the genetic variation has a major influence on the varying adaptive potential of the investigated populations.

Keywords: Fagus sylvatica, drought, desiccation, mortality, LD50 ${ }_{\text {SWA }}$, soil water availability, genetic variation, pre-dawn water potential 


\section{INTRODUCTION}

There is much evidence that ongoing climate change is warming the global climate system given the average temperature rise of $0.85^{\circ} \mathrm{C}$ for the combined land and ocean surface over the period from 1880 to 2012. And there is strong evidence that an increased frequency of extreme weather events like heat waves and precipitation extremes is linked to global warming (Coumou and Rahmstorf, 2012). Projections of further warming in the Twenty-first century are linked to a likely increase in, and intensification of, heat waves and drought periods, in particular toward the end of the century (IPCC, 2013). For Europe it has been found, that the severity, duration, and frequency of drought events increased from 1950 to 2012 in Mediterranean regions, but moderately also in parts of Central Europe (Spinoni et al., 2015). Similar tendencies are also projected for the future (IPCC, 2012; Stagge et al., 2015). European forests have already responded to more intensive drought impacts with increased mortality (Allen et al., 2010).

The natural vegetation in Central Europe and higher elevated areas in southern Europe is dominated largely by European beech (Fagus sylvatica L.; Bohn et al., 2004; Bréda et al., 2006). Besides being of high economic value, beech is also of ecological importance, since it is the dominant tree species in many forest ecosystems (Leuschner et al., 2006). Beech can grow well on a wide variety of sites except on extremely dry soils with low water storage capacity, stagnic soils, or soils prone to flooding and high ground water table (Ellenberg and Leuschner, 2010). Beech is dominant in many deciduous forests in Europe under maritime and temperate climate conditions with mild winters and moist summer conditions; the pronounced cold, dry, and continental climate limits its distribution (Bolte et al., 2007). As a distinct shade-tolerant tree species, beech itself reduces below-canopy irradiance often below $5 \%$ of the open field irradiance (Emborg, 1998; Collet et al., 2001), giving it the competitive advantage over other tree species (Ellenberg and Leuschner, 2010).

However, beech is generally reputed to be sensitive to drought (e.g., Aranda et al., 2000; Gessler et al., 2007) and could lose its competitive advantage to less drought-sensitive species like sessile oak [Quercus petraea (Matt.) Liebl.] under water-limited conditions (Scharnweber et al., 2011). Looking on direct drought impact, beech's vulnerability to cavitation seems to make it extremely sensitive to singular extreme water deficit, and hence to drought (Barigah et al., 2013; Urli et al., 2013). A critical internal water status in beech seedlings is reached at shoot water potential of -1.9 MPa (Hacke and Sauter, 1995) upon which a loss of hydraulic conductivity may eventuate. In case of continuing drought, $50 \%$ loss of hydraulic conductivity (P50) can occur between -2.0 MPa and -3.0 MPa (Cochard et al., 1999; Cruiziat et al., 2002). A critical loss of hydraulic conductivity (P88) was found at $-4.2 \mathrm{MPa}$ (Urli et al., 2013), and Barigah et al. (2013) reported $50 \%$ mortality among beech seedlings at $-4.5 \mathrm{MPa}$ plant water potential (xylem pressure). During the extreme drought year 2003, Granier et al. (2007) identified 40 and $20 \%$ of relative available soil water content as thresholds below which gross primary production, and total ecosystem respiration decreased respectively. However, there is still no coherent approach to link quantitatively the environmental drought impact, e.g., assessed as soil water deficit, to the desiccation and mortality of tree seedlings. Bréda et al. (1995) and Czajkowski et al. (2009) demonstrated that plant water status can be linked to soil matrix potential at the lower end of the effective rooting zone (ERD). Accordingly, a simultaneous study of soil hydraulic traits and desiccation dynamics may link plant mortality to soil water deficit, not at an individual, but also at a mean population level. Such an indicator can be applied in regional assessments and projections on soil water availability and critical drought risk (e.g., Bolte, 2015).

In Central Europe, beech exhibits high genetic diversity within populations (Vornam et al., 2004), but genetic differentiation between populations is also evident at continental scale (Magri et al., 2006; Dounavi et al., 2016). Accordingly, several studies on young beech seedlings revealed remarkable differences in the adaptive potential of different beech populations to drought: beech populations from the xeric sites and/or range margins seem to have a higher drought tolerance than those from mesic sites and/or central ranges (Italy: Tognetti et al., 1995; Bosnia and Herzegovina: Ivojević et al., 2012; Slovakia: Pšidová et al., 2015; Germany: Schraml and Rennenberg, 2002; Peuke et al., 2002; Poland and Germany: Czajkowski and Bolte, 2006a; Rose et al., 2009; Spain, Bulgaria and Germany: Thiel et al., 2014; Germany, Balkan peninsula, Bulgaria and Greece: Dounavi et al., 2016). This response could be due to population dynamic processes at the southern and eastern margins of the beech distribution range including local, evolutionary adaptation to increasing drought stress on xeric sites (Hampe and Petit, 2005).

Except for the regional study by Ivojević et al. (2012), the previous experimental studies on population level focused on seedling growth performance, hydraulic traits, and/or water status under moderate or severe drought, but did not systematically apply severe drought, which induces mortality among the seedlings. Thus, a continental study of beech seedling mortality induced by extreme drought events and variation in mortality among populations level is lacking. Using the panEuropean EU Cost STReESS network, we collected seeds from seven sites in six European countries throughout the native beech range and conducted a common garden experiment in Germany to (1) derive a desiccation and mortality indicator at the population level that can be related to soil water availability (SWA), (2) derive critical limits of soil water availability (SWA) for the studied beech populations, and (3) reveal possible population variation in extreme drought response and desiccation.

\section{MATERIALS AND METHODS}

\section{Plant Material}

For the experiments, we collected at least $1 \mathrm{~kg}$ of fresh beech seeds from four different autochthonous, old-growth beech stands [location see Table 1; population Stenderup Midskov (Denmark), Nevesinje (Bosnia), Valea Boronului (Romania), and Erro (Spain)]. The collected seeds originated from at least ten different old-growth beech individuals. Seeds from three other 
populations originated from commercial seedbanks (Crecy and Montagne Noir, France) and Sellhorn (Germany), which were also collected in single stands. The stand locations cover a large variety of environments within the natural beech distribution range, in particular including geographically marginal sites (Figure 1). For the climatic characterization of the population origins, we used temperature and precipitation parameters and the Ellenberg Climate Quotient EQ (Ellenberg, 1988, Equation 1):

$$
E Q=\left(\frac{T_{\text {max. }}}{P_{\text {year }}}\right) \cdot 1000
$$

where $T_{\text {max }}$. is the mean temperature in the warmest month $\left({ }^{\circ} \mathrm{C}\right)$ and $P_{\text {year }}$ the total annual precipitation $(\mathrm{mm})$.

Moreover, we applied De Martonne (1926) Aridity index Am (Equation 2):

$$
A m=\left(\frac{P_{y e a r}}{T_{\text {year }}+10}\right)
$$

with the annual mean temperature $T_{\text {year }}\left({ }^{\circ} \mathrm{C}\right)$. The found ranges of climatic parameters (Table 1) cover quite well the climatic range limits of European beech reported by Fang and Lechovicz (2006) with e.g., $T_{\text {year }}\left({ }^{\circ} \mathrm{C}\right)$ ranging from 7.2 to 13.5 and $E Q$ from 16.8 to 29.0 , but not reaching the absolute xeric extremes. However, our exceedance of EQ limits on higher elevated sites (PV6, PV7) may indicate the problem to adequately characterize both lowland and mountainous climatic limits with indices mainly based on annual means, only.

The seeds were collected in autumn 2013, stored and transported in cool, dry environments to the Thünen Institute of Forest Genetics in Groß-Hansdorf (Germany). Uniformly sized seeds of each population were surface-sterilized by soaking in $3 \%$ sodium hypochlorite for $5 \mathrm{~min}$ and rinsing with deionized water. Thereafter, a stratification procedure was performed: (1) the seed moisture content was reduced to about $8 \%$ of the fresh seeds' moisture content (e.g., by storing them $\approx 1$ week in a cool, dry place), (2) seeds were preserved in plastic bags in a freezer at $-5^{\circ} \mathrm{C}$ until mid-February (stratification by frost), (3) the seed moisture was increased at a temperature of $3-5^{\circ} \mathrm{C}$ (using a water sprayer); (4) as soon as the first little sprout was visible, the seedlings were transplanted into pots. With this procedure at least 200 individual seedlings per population were available for the drought experiments.

After the success of seed germination was recorded, plants were cultivated in cylindrical PVC pots (1.4 liters) filled with $70 \%$ silty sand (grain size $0-2 \mathrm{~mm}$ ), 30\% peat-based substrate mixed with with $2 \mathrm{~kg} \mathrm{~m}^{-3}$ Osmocote (NPK 14:13:13+7SO 3 , plus micro elements). Plants grew under slightly reduced open field light conditions $(\approx 70 \%$ rel. open field irradiance $)$ in a greenhouse environment.

After transferring the seedlings to the Thünen Institute of Forest Ecosystems in summer 2014, a drought simulation was carried out in late summer 2014 in a greenhouse at the University of Sustainable Development (HNE) in Eberswalde $\left(52^{\circ} 49^{\prime} 28^{\prime \prime} \mathrm{N}\right.$ $13^{\circ} 47^{\prime} 29^{\prime \prime} \mathrm{E}, 30 \mathrm{~m}$ a.s.1.). Within the treatment period relative air humidity averaged $69 \%$, with a minimum of $30 \%$ and a maximum of $88 \%$. Air temperature ranged between $11^{\circ} \mathrm{C}$ (minimum during night) and $31^{\circ} \mathrm{C}$ (maximum during day), and attained a mean of $19.0^{\circ} \mathrm{C}$. The plants grew under ambient light conditions during the experiment without any additional illumination. During the experiment the light intensity never exceeded $1000 \mu \mathrm{mol}$ photons $\mathrm{m}^{-2} \mathrm{~s}^{-1}$ under sunny conditions.

Plant traits before the commencement of the drought experiment (Table 2) show some variation in root collar diameter, plant height and leaf number among the populations, but a common pattern across populations was not observed. No significant differences were found for total leaf area.

\section{Experimental Set-up}

For the experimental drought simulation, 100 seedlings per population were arranged in the two variants: "control" (C) in 20 pots and "drought treatment" (D) in 80 pots. The seedlings of the different populations were kept together in groups on trolleys in the greenhouse, but population groups were randomly moved and thus spatially re-arranged every 3 days. The group of "control" seedlings was maintained close to field capacity (FC) by frequent watering; whereas, water supply was suspended for those seedlings subjected to drought treatments. Before beginning the drought experiment, initial soil water content and soil dry weight was assessed by weighing samples of the used soil substrate before and after oven drying at $105^{\circ} \mathrm{C}$ for $48 \mathrm{~h}$. Pots then were watered to saturation. After excess water had drained away, field capacity (FC, Blume et al., 2016) was reached at around $-0.06 \mathrm{MPa}$ soil water potential ( $\mathrm{pF} 1.8)$, and the initial field capacity (FC) pot weight was derived. By subtracting the soil dry weight from FC pot weight we derived the initial soil water content at field capacity. Subsequent changes in pot weight were attributed to changes in soil water content.

The available water capacity $\left(\theta_{\mathrm{AWC}}\right)$ of the soil was derived using following Equation (3, cf. Veihmeyer and Hendrickson, 1927).

$$
\theta_{\mathrm{AWC}}=\theta_{\mathrm{FC}}-\theta_{\mathrm{PWP}}
$$

where $\theta$ is the soil water content $[\mathrm{g}]$ at field capacity (FC, pF 1.8 $\approx-0.06 \mathrm{MPa}$ soil water potential) and at the permanent wilting point (PWP, $\mathrm{pF} 4.2 \approx-1,5 \mathrm{MPa}$ soil water potential). $\theta_{\mathrm{PWP}}$ was derived from a soil water characteristic $(\mathrm{pF})$ curve established for the used soil substrate. With this definition we follow the concept of Reid et al. (1984) who induced the term available soil water for laboratory assessments in contrast to extractable soil water for field estimates (Ritchie, 1981).

The residual soil water availability (SWA) [\%] (Equation 4) is defined as the actual soil water content $\left(\theta_{\mathrm{t}}\right)$ [g] during drought treatment expressed as a percentage of the initial available soil water capacity $\left(\theta_{\mathrm{AWC}}\right)[\mathrm{g}]$, and corresponds to the relative extractable soil water (REW) in field studies, Granier et al., 2007):

$$
S W A=\frac{\theta_{t}}{\theta_{A W C}}
$$

To assess SWA, each pot was weighed three times per week after watering was stopped. The treatment started in mid-summer $(06 / 08 / 2014)$ and lasted for 8 weeks until all seedlings were considerably desiccated. 
TABLE 1 | Temperature (T) and precipitation (P) [year, growing season from April (4) to September (9)] at the origin of the seedling populations, derived from WorldClim grid data (Source: http://www.worldclim.org/current, period 1950-2000, ESRI grid, resolution $30 \mathrm{~s}$, ca. 1 km²).

\begin{tabular}{|c|c|c|c|c|c|c|c|c|c|c|c|c|}
\hline No. & Population & Country & Lat. $\mathbf{N}\left({ }^{\circ}\right)$ & Long. E $\left(^{\circ}\right)$ & Alt. asl. (m) & $\mathrm{T}$ year $\left({ }^{\circ} \mathrm{C}\right)$ & T 4-9 $\left({ }^{\circ} \mathrm{C}\right)$ & Tmax. $\left({ }^{\circ} \mathrm{C}\right)$ & P year $(\mathrm{mm})$ & P 4-9 (mm) & $E^{a}$ & $A m^{b}$ \\
\hline PV1 & $\begin{array}{l}\text { Stenderup } \\
\text { Midtskov }\end{array}$ & DK & 55.47 & 9.65 & 18 & 7.7 & 11.2 & 15.8 & 720 & 352 & 21.9 & 40.7 \\
\hline PV2 & Sellhorn & $\mathrm{DE}$ & 53.35 & 9.93 & 86 & 8.2 & 12.1 & 16.9 & 748 & 402 & 22.6 & 41.1 \\
\hline PV3 & Crecy & $\mathrm{FR}$ & 50.25 & 1.88 & 30 & 10.5 & 13.7 & 17.5 & 637 & 291 & 27.3 & 31.1 \\
\hline PV4 & $\begin{array}{l}\text { Montagne } \\
\text { Noir }\end{array}$ & $\mathrm{FR}$ & 43.50 & 2.22 & 341 & 12.4 & 16.1 & 20.7 & 791 & 376 & 26.2 & 35.3 \\
\hline PV5 & $\begin{array}{l}\text { Valea } \\
\text { Baronului }\end{array}$ & $\mathrm{RO}$ & 44.77 & 21.68 & 445 & 9.3 & 14.5 & 19.6 & 722 & 424 & 27.0 & 37.4 \\
\hline PV6 & Nevesinje & $\mathrm{BA}$ & 43.27 & 18.13 & 862 & 9.6 & 13.7 & 18.8 & 1199 & 493 & 15.7 & 61.2 \\
\hline PV7 & Erro & ES & 43.00 & -1.47 & 931 & 9.1 & 12.9 & 17.2 & 1166 & 511 & 14.7 & 61.0 \\
\hline
\end{tabular}

Altitude values represent the means of the 30 s grid cell.

${ }^{a} E Q$ : Ellenberg Climate Quotient.

${ }^{b}$ Am: Aridity index of De Martonne.

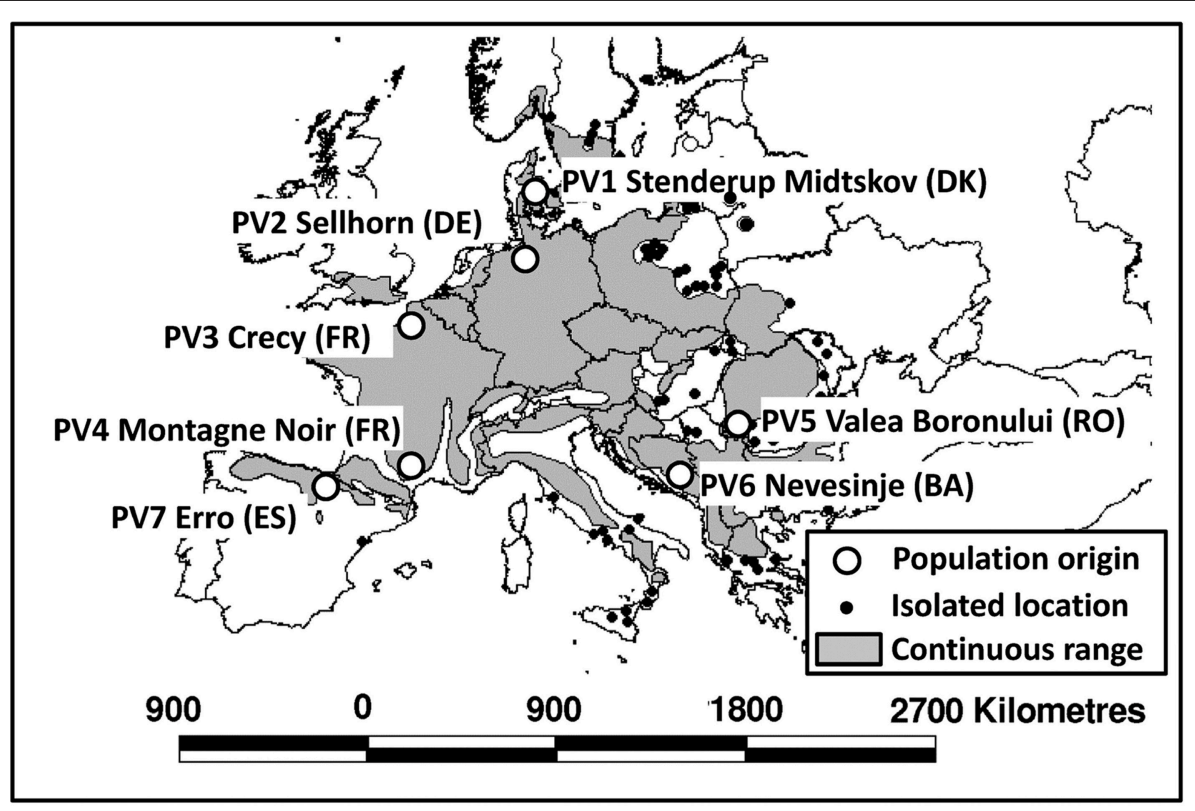

FIGURE 1 | Location of the origins of the investigated populations (circles), and continuous distribution range of European beech (gray area) based on the distribution map of Bolte et al. (2007).

\section{Desiccation and Mortality Assessments}

During the drought treatment, the advanced plant desiccation process was monitored by measuring individual pre-dawn leaf water potentials $\left(\Psi_{\mathrm{PD}}\right)$ with the Scholander chamber technique (Scholander et al., 1964, using the Plant Moisture Vessel Skye SKPM 1400, Skye Instruments, Llandrindod Wells, UK). $\Psi_{\mathrm{PD}}$ was measured between 0:00 and 5:00 (UT). Seedlings with first optical signs of wilting were measured during the desiccation process. They were regarded as dead when signs of complete wilting occurred with yellow-brown discoloration of the entire leaf surface. To control the status of complete cavitation ( $>88 \%$ loss of hydraulic conductivity at MPa $<$ $-6 \mathrm{MPa})$ we measured pre-dawn water potential of the wilted plants.
The completely wilted plants were separated from the treatment group and re-watered. The date of obvious mortality was recorded. This mortality definition neglects the possibility of wilted beech seedling resprouting after re-watering that were assessed in the following spring 2015. However, the majority of the few found resprouted beech plants died in the days and weeks later due to unspecific reasons which made the viability re-assessment unreliable.

\section{Derivation of Critical Drought LD50}

For comparing the mortality dynamics of the different beech seedling populations, we adopted the approach for drought impact analyses by Kursar et al. (2009). Due to this, the median lethal desiccation $\left(\mathrm{LD}_{50}\right)$ describes the drought impact that leads 
TABLE 2 | Means ( \pm standard error) of plant traits for the beech seedlings before the drought stress experiment.

\begin{tabular}{|c|c|c|c|c|c|c|}
\hline No. & Population & Country & Root collar diameter (mm) & Plant height (cm) & Leaf area $\left(\mathrm{cm}^{2}\right)$ & Leaf number (n) \\
\hline PV1 & Stenderup Midtskov & DK & $2.00^{b} \pm 0.00$ & $14.67^{b} \pm 0.32$ & $77.11 \pm 5.47$ & $9.50^{b} \pm 0.90$ \\
\hline PV2 & Sellhorn & $\mathrm{DE}$ & $2.44^{a} \pm 0.09$ & $12.44^{\mathrm{b}} \pm 0.32$ & $99.62 \pm 12.70$ & $13.13^{a, b} \pm 2.38$ \\
\hline PV3 & Crecy & FR & $2.25^{a} \pm 0.10$ & $17.50^{\mathrm{a}} \pm 0.40$ & $99.44 \pm 12.19$ & $12.75^{a, b} \pm 1.50$ \\
\hline PV4 & Montagne Noir & $\mathrm{FR}$ & $2.45^{a} \pm 0.11$ & $14.92^{a, b} \pm 0.76$ & $69.99 \pm 11.50$ & $4.40^{C} \pm 0.57$ \\
\hline PV5 & Valea Baronului & $\mathrm{RO}$ & $2.00^{b} \pm 0.00$ & $15.42^{\mathrm{a}} \pm 0.47$ & $111.25 \pm 16.12$ & $15.00^{\mathrm{a}} \pm 1.64$ \\
\hline PV6 & Nevesinje & $\mathrm{BA}$ & $2.75^{a} \pm 0.10$ & $16.77^{a} \pm 0.79$ & $110.43 \pm 7.47$ & $15.63^{\mathrm{a}} \pm 1.64$ \\
\hline PV7 & Erro & ES & $2.00^{b} \pm 0.00$ & $13.80^{b} \pm 0.45$ & $90.12 \pm 11.61$ & $9.63^{b} \pm 2.27$ \\
\hline
\end{tabular}

Means followed by different letters are significantly different at $p<0.05$ (ANOVA, test of population differences, comparison downwards), means of leaf area are not significantly different.

to $50 \%$ mortality in the seedling population in comparison to the control treatment (cf. also Ivojević et al., 2012). In our study, LD50 ${ }_{\text {SWA }}$ defines the drought impact as the residual soil water availability (SWA [\%]), which is linked to a $50 \%$ mortality rate in the population according to previously reported mortality definition.

The critical soil water availability (LD50 ${ }_{\text {SWA }}$ ) per seedling population (drought treatment) was derived from a doseresponse analysis of mortality rate $M$ (Equation 5 ) and survival rate $S$ (Equation 3) as a function of soil water availability ( $S W A$ ) depletion over time:

$$
M_{S W A}=\frac{\sum_{S W A_{i}}^{S W A} m_{a}}{n_{a}},
$$

where $m_{a}$ is the number of dead plants $m$ in population $a, n_{a}$ is the number of total plants per population $a$ in the drought experiment $\left(n_{a}\right)$ and period between initial soil water availability $S W A_{i}$ and current soil water availability $S W A$.

The survival rate $S$ (Equation 6) was then calculated from the mortality rate $M$ :

$$
S_{S W A}=1-M_{S W A}
$$

The survival rate $S$ (range $0-1$ ) was fitted by a non-linear regression analysis applying the software package SAS JMP 11.0 (SAS Institute Inc, 2014). For this we used a two-parameter logistic model (2PL) of the following form to derive the survival function $s$ (Equation 7) related to soil water availability (SWA) depletion over time:

$$
S_{S W A}=\frac{1}{1+e^{\left[-\beta_{0}\left(S W A-\beta_{1}\right)\right]}},
$$

where two empirical parameters describe the growth rate $\left(\beta_{0}\right)$ and the inflection point $\left(\beta_{1}\right)$.

For the symmetric 2PL model used, the LD50 SwA $_{\text {values of }}$ the different provenances equate with inflection points $\left(\beta_{1}\right)$ at $S_{\text {SWA }}=0.5$ (Gregorczyk, 1991; SAS Institute Inc, 2014).

We tested the fitted models between the different populations for parallelism using a F-Test. The test compares the error sumsof-squares for a full and a reduced model. The full model gives each group different parameters. The reduced model forces the groups to share every parameter except for the inflection point.
Moreover, the equality of model parameters across the levels of the populations, used as a grouping variable, was considered. With a comparison of parameter estimates (CPE), including an Analysis on Means (ANOM), the population means are tested against the overall mean.

The effect of decreasing soil water availability (SWA) on the plant internal water status, indicated by the predawn water potential, is indicative for the loss of water conductivity and cavitation, finally leading to hydraulic failure (e.g., Urli et al., 2013). Thus, besides relationships between LD50 SWA $_{\text {and }}$ climate variables at population origin also correlations between soil water availability (SWA) and mean predawn water potentials $\left(\Psi_{\mathrm{PD}}\right)$ of the seedlings were analyzed by single linear regression analyses and F-test. Before the regression analysis (SWA vs. $\left.\Psi_{\mathrm{PD}}\right)$ we multiplied the $\Psi_{\mathrm{PD}}$ values by -1 to derive positive values and then log-transformed both parameters. A linear model was fitted, and values and model were then re-transformed [log $\left(\mathrm{SWA},-\Psi_{\mathrm{PD}}\right)$ ] resulting in a non-linear power function as a nonlinear regression model. A bias correction was not applied. We tested the equality of the model across the populations using the already above mentioned tests on parallelism, CPE and ANOM. For all statistical analyses described and modeling purposes, $p<$ 0.05 was considered significant.

\section{RESULTS}

\section{Soil Water Availability and Seedling Mortality}

During the drought treatment, initial mortality of the seedlings was observed between 34 and 43 days from the commencement of the experiment. At the end of the experiment, mortality ranged between 33\% (PV4, Montagne Noir, France) and 71\% (PV1, Stenderup Midtskov, DK). A considerable increase in seedling mortality occurred when soil water availability (SWA) fell below values of 30-20\% (Figure 2). However, differing responses between populations were found with respect to seedlings mortality dynamics under soil water depletion. The largest differences were found between PV1 (Stenderup Midtskov, DK) and PV3 (Crecy, FR). PV1 mortality started late (22\% SWA), but had the strongest increase in mortality (growth rate $\beta_{0} \approx 0.85$, Table 3) overtaking all other populations in final mortality (0.62). In contrast, PV 3 mortality began already at 27\% SWA, followed by a retarded progress in mortality (growth rate $\beta_{0} \approx 0.24$, 


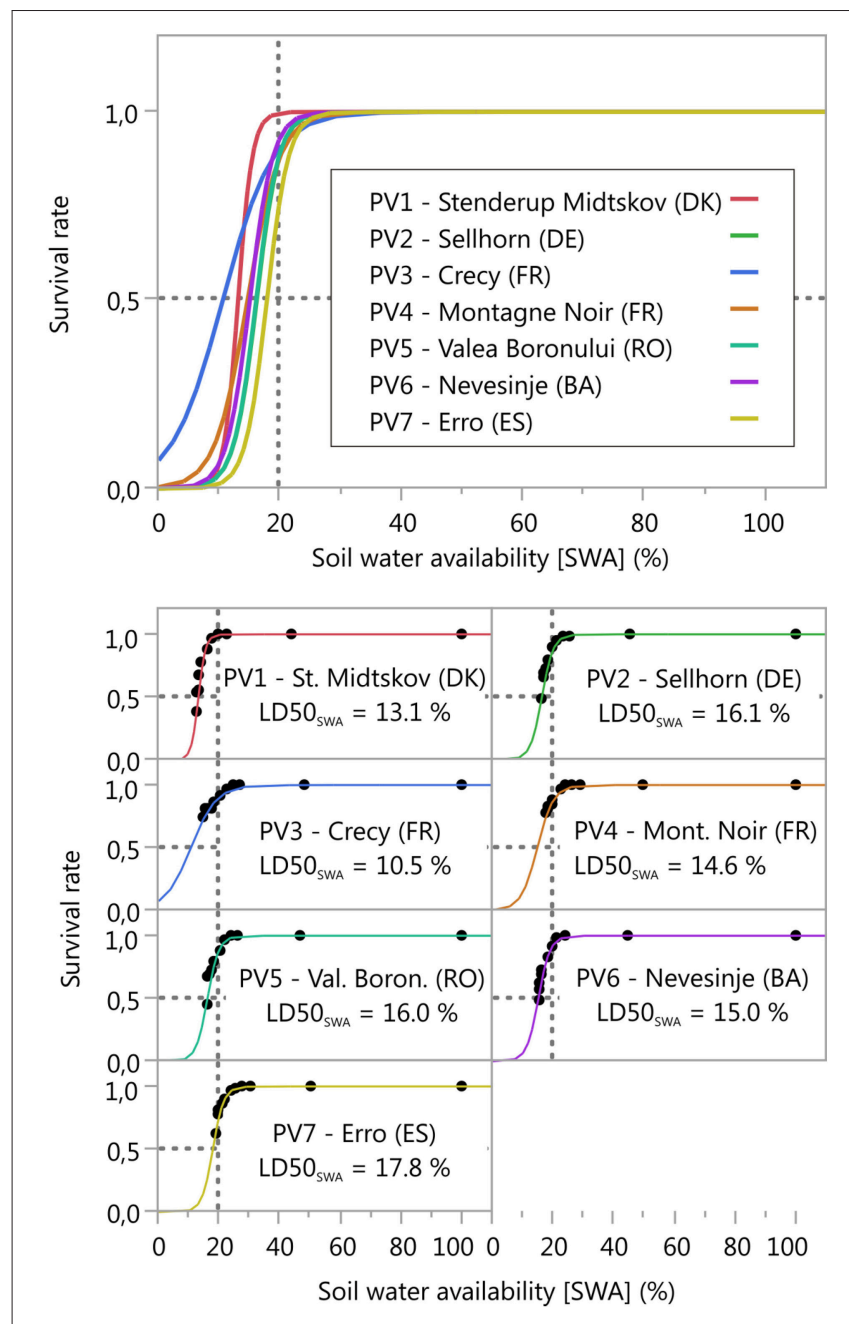

FIGURE 2 | Relationship between soil water availability [SWA] (\%) and the survival rate, critical soil water availability (LDSOswA) derived from the $2 \mathrm{PL}$ model $(50 \%$ mortality at the inflection point = LDSOswAI see chapter on analyses). The $20 \%$ SWA line found to be a critical threshold for plant performance by other studies (e.g., Granier et al., 2007; Domec et al., 2015) is displayed for orientation. Further information is shown in Table 3

Table 3), not reaching 50\% mortality at the end of the drought simulation. The mortality dynamics in terms of growth rate of the other populations were within this range. Correspondingly, growth rate $\left(\Omega_{0}\right)$ varies significantly from the overall mean parameter for PV1 (Stenderup Midtskov, DK) by exceeding the upper limit (UPL) and, for PV3 (Crecy, FR), by undershooting the lower limit (LWL) according to the comparison of parameter estimates (CPE, Table 3). The different shape of the fitted models $\left(B_{0}\right)$ was also significant according to a parallelism F-test (F value $6.063, p<0.0001)$.

The LD50 5 wA values corresponded to the inflection point of the model ( $\beta_{1}$, Table 3$)$. High LD50 ${ }_{\text {SWA }}$ values were found for the populations PV2 (Sellhorn, DE), PV5 (Valea Boronului) and PV7 (Erro, ES), indicating high drought sensitivity (Figure 2). Low

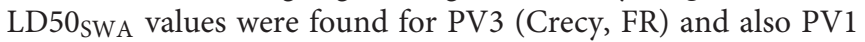
(Stenderup Midtskov, DK). LD50 ${ }_{\text {SWA }}$ of all populations differed significantly from an overall mean except for PV4 (Montagne Noir, FR) looking on CPE results (Table 3).

The analyses revealed that seedlings' mortality dynamics and the critical threshold for drought impact indicated by LD50 differ significantly among the selected populations. The most drought tolerant population in our experiment was PV3 (Crecy, FR) whereas the populations from higher elevations (PV5, PV6, and PV7) and northern origin (PV2) were drought sensitive. The most northern population (PV1, Stenderup Midtskov, DK) exhibited a remarkably strong drop in seedling survival that revealed sudden drought mortality risk for low SWA. A considerable extrapolation of $50 \%$ mortality is visible when applying the model to the two French populations (PV3, PV4), and thus the LD50swA values for both populations have to be considered with care. However, the extrapolated LD50swA values are supported by the clearly retarded mortality dynamics below $20 \%$ remaining SWA and the lower (negative) growth rate $\left(B_{0}\right)$ of the regression model for both French populations compared to the other ones.

\section{Relationships between LD50 SWA $_{\text {A }}$ and Climate Variables}

The critical soil water availability (LD50 SWA $_{\text {) }}$ correlated significantly $(p<0.05, r=0.73$ ) with the mean growing season precipitation (Prec. 4-9, Figure 3, middle below). This relationship did not correspond to the geographical North-South gradient of the population origin, but is more influenced by the altitudinal precipitation gradient. No statistical relationships were found for temperature parameters (Ty, $\mathrm{T}_{4-9}$, T. max, latter not shown). Some tendencies are visible for mean annual precipitation sum (Py) and the climate indices used, which combined temperature and precipitation parameters (EQ, Am), but here the correlations between the climate parameter and the LD50 SwA values were not significant.

\section{Soil Water Availability and Internal Water Status}

The soil water availability (SWA) was closely correlated to the internal water status of the beech seedlings considered by the predawn water potentials ( $\Psi_{\mathrm{PD}}$, Figure 4A). Due to observed heteroscedasticity the estimates are not unbiased. The figure shows population means of SWA and pre-dawn potentials of selected plants with signs of desiccation (treatment) or irrigated control plants (control) without drought stress. Plants without desiccation or indication of visible wilting during the drought treatment were not included. Mean values refer to nine dates during the experiment between the 33 th and $61^{\text {st }}$ day after its start. A distinct change in $\Psi_{\mathrm{PD}}$ values was visible when SWA dropped below $20 \%$, corresponding to $\Psi_{\mathrm{PD}}$ of $-2 \mathrm{MPa}$. Small decreases in SWA below this threshold led to a strong drop in $\Psi_{\mathrm{PD}}$ values in wilting plants, which correspond to the mean mortality dynamics shown in Figure 2. In contrast to mean mortality dynamics, the tests on parallelism and equality of the model parameters gave no significant indication of variation across the populations $(p<0.05)$. Thus we used the general regression model to estimate the mean predawn water potentials 
TABLE 3 | Non-linear regression model parameters (growth rate $\beta_{0}$, inflection point $\beta_{1}$ ) and their standard error (SE) for predicting survival of beech seedlings from soil water availability (SWA), see Equation (4, 2PL) and Figure 2.

\begin{tabular}{|c|c|c|c|c|c|c|c|}
\hline & PV1 Stenderup Midtskov & PV2 Sellhorn & PV3 Crecy & PV4 Montagne Noir & PV5 Valea Baronului & PV6 Nevesinje & PV7 Erro \\
\hline$\beta_{0} \pm S E$ & $0.85 \pm 0.10$ & $0.53 \pm 0.06$ & $0.24 \pm 0.05$ & $0.37 \pm 0.08$ & $0.54 \pm 0.06$ & $0.52 \pm 0.06$ & $0.56 \pm 0.09$ \\
\hline UPL & 0.72 & 0.62 & 0.58 & 0.68 & 0.62 & 0.62 & 0.70 \\
\hline LWL & 0.19 & 0.29 & 0.33 & 0.23 & 0.29 & 0.30 & 0.21 \\
\hline$B_{1} \pm S E$ & $13.058 \pm 0.0777$ & $16.116 \pm 0.183$ & $10.525 \pm 1.231$ & $14.592 \pm 0.939$ & $16.030 \pm 0.176$ & $14.972 \pm 0.160$ & $17.797 \pm 0.358$ \\
\hline UPL & 14.347 & 14.630 & 17.428 & 16.647 & 14.610 & 14.567 & 15.097 \\
\hline LWL & 13.932 & 13.650 & 10.852 & 11.632 & 13.671 & 13.713 & 13.183 \\
\hline
\end{tabular}

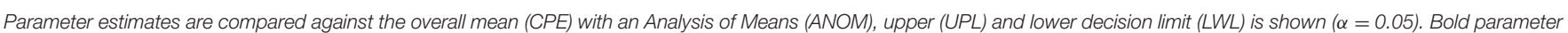
values $\left(B_{0}, B_{1}\right)$ deviate significantly from the overall mean. Overall goodness of fit measures: Akaike information criterion $A I C C_{C}=-295.87, S S E=0.059, M S E=0.00093, r^{2}=0.97$.
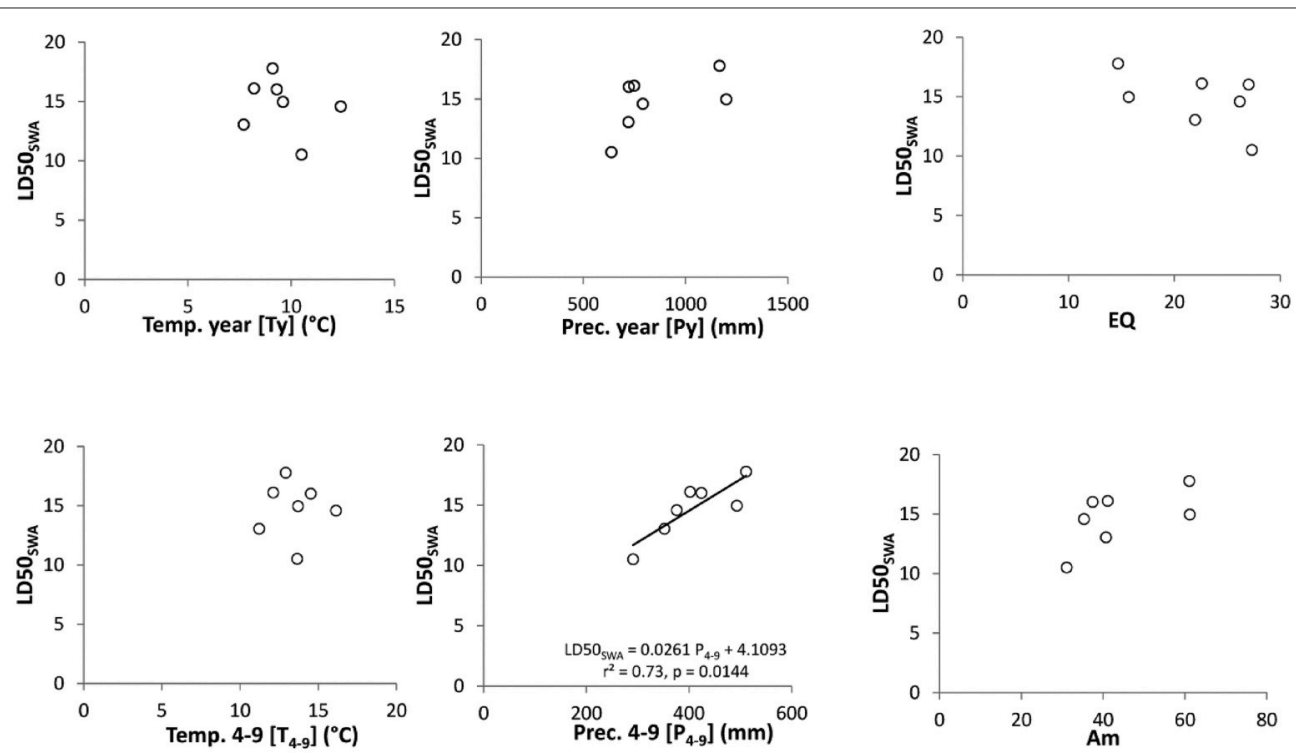

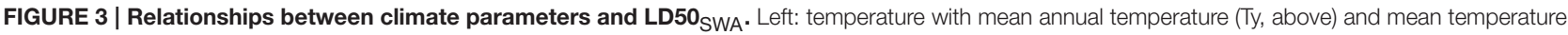
during growing season $\left(\mathrm{T}_{4-9}\right.$, below); middle: precipitation with mean annual precipitation (Py, above) and mean precipitation during growing season ( $\mathrm{P}_{4-9}$, below); right: climate indices with Ellenberg Climate Quotient (EQ, above) and Aridity index of De Martonne (Am, below). The linear regression line displays a significant predictor effect of precipitation during the growing season $\left(\mathrm{P}_{4-9}\right)$ on LDSOswA (seep values).

$\left(\Psi_{\mathrm{PD}}\right)$ when $50 \%$ mortality was reached (LD50 $\mathrm{SwA}$ ) for the different populations (Figure 4B, inlayed figure). The large variation of $\Psi_{\mathrm{PD}}$ values from nearly $-5 \mathrm{MPa}$ for PV3 (Crecy, $\mathrm{FR}$ ) to $-2.3 \mathrm{MPa}$ for PV7 (Erro, ES) is induced by variation in LD50 SWA $_{\text {below } 20 \% \text { SWA. }}$

\section{DISCUSSION}

\section{LD50 as a Critical Threshold of Drought Impact}

The outcome of our study demonstrates that the derived LD50 ${ }_{\text {SWA }}$ indicator is useful for analyzing the drought sensitivity of young trees. L50 was developed and first applied as a lethal dose or concentration indicator referring to $50 \%$ mortality of organism populations (Cavalli-Sforza, 1972) for dose-response analysis in the field of toxicology. In plant ecology, it was quite commonly used for lethal temperature (frost) impact on plants, including also trees (LT50, e.g., Zhang and Willison, 1987; Barranco et al., 2005; Kreyling et al., 2014; Hofmann et al., 2015). Some examples for the use of L50 approaches to indicate drought impact (LD50) considered exposure time only (Ivojević et al., 2012; Granda et al., 2015). Results of those studies, however, are only valid for the specific experimental environments used (e.g., pot size, soil substrate and plant material) and cannot be generalized or transferred to other environments. Kursar et al. (2009) presented an alternative approach of using leaf water status (relative leaf water content $R W C$, leaf water potentials $\Psi)$ as a quantitative plant-related parameter for lethal drought assessment (LD50 ${ }_{\mathrm{RWC}, \Psi}$ ) providing more general results for tree

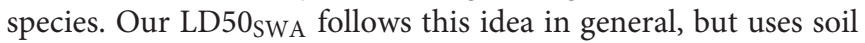
water availability (SWA), which can be consistently assessed for different soil substrates in relation to different absolute available soil water amounts (cf. Meir et al., 2015). This provides new 


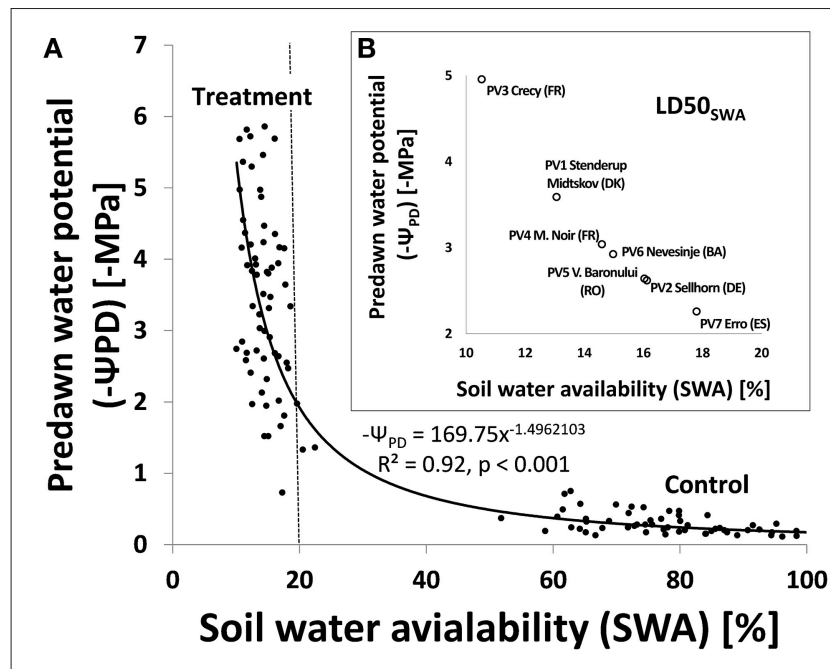

FIGURE 4 | (A) Relationship between soil water availability (SWA) and negative predawn water potential $\left(-\psi_{\mathrm{PD}}\right)$. Each point represents the population means at 9 dates from 33 to 61 days after the start of the drought experiment (treatment and control samples). Only seedlings with a predawn water potential $>-6 \mathrm{MPa}$ are included. The fitted model curve was derived from a linear regression analysis of Jog-transformed SWA and - $\psi$ PD values [ $\log$ SWA = $\left.212298002-114962103 \log \left(-\psi_{P D}\right)\right]$. Values and model curve were then re-transformed $[10 \mathrm{log}(\mathrm{SwA},-\psi \mathrm{PD})]$ resulting in above displayed graph and power function; (B, inlaid figure) Estimated mean predawn water potentials when the different beech populations reached LDSO SWA using the relationship described in Figure 4A.

possibilities in soil water modeling for plant-related drought risk approaches (Bolte, 2015). However, a reference soil depth has to be defined describing the soil-root interface for water uptake, generally defined as effective rooting depth (ERD, cf. Czajkowski et al., 2009). This concept is supported by the simultaneous study of soil water and plant water status along the rooting gradient in mature oak stands in France, which reveals substantial water depletion dynamics down to the lower end of rooting zone corresponding to ERD (Bréda et al., 1995). In our experiment the entire pot depth that was completely rooted at the end of the experiment was regarded as ERD.

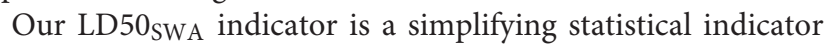
for drought impact at the population level, complementing and not replacing functional assessments and theories of extreme drought impact and plant mortality at an individual level (in particular hydraulic failure theory, Sperry et al., 1998; Brodribb and Cochard, 2009; Barigah et al., 2013). It also has to be considered in the context of other parameters like the mortality dynamics with decreasing SWA (Table 3, slope of regression model $\beta_{o}$ ). However, the L50 swA result range of about $10-18 \%$ lethal soil water availability shown fits well to reported threshold of $20 \%$ available soil water told to induce strong effects, but not automatically mortality in mature trees and stands like the drop of whole tree hydraulic conductance (Domec et al., 2015) and the decrease in total ecosystem respiration TER (Granier et al., 2007). Thus, we regard LD50 ${ }_{\text {SwA }}$ as a valid indicator that links plant-internal water status to soil hydraulics and by this provide novel possibilities for climate-soil water modeling and regionalisation of drought risk from plant to landscape and regional level. Recently, this approach was used for modeling the recent and future risk of lethal drought impact on beech regeneration by assessing period length below the LD50 SWA $_{\text {value }}$ under the canopy of mature stands of Norway spruce, Scots pine, and European beech on the national scale in Germany (Bolte, 2015).

\section{Different Drought Response of Populations}

Both our significant genetic differentiation of in LD50 5 A values $(\approx 10-18 \%$, Figure 2 , Table 3 ) and the varying mortality dynamics ( $\beta_{0}$, Table 3 ) among the different populations support the idea of local adaptation of populations within the European beech range. This is in line with many other studies on (1) leaf phenology (Wuehlisch et al., 1995; Chmura and Rozkowski, 2002; Nielsen and Jørgensen, 2003; Čufar et al., 2012; Robson et al., 2013), (2) cambium, xylem and phloem phenology (Prislan et al., 2013; Martínez del Castillo et al., 2016), (3) frost tolerance (Visnjic and Dohrenbusch, 2004; Czajkowski and Bolte, 2006b; Kreyling et al., 2014), and (4) drought response (Tognetti et al., 1995; García-Plazaola and Becerril, 2000; Peuke et al., 2002; Schraml and Rennenberg, 2002; Czajkowski and Bolte, 2006a; Rose et al., 2009; Ivojević et al., 2012; Eilmann et al., 2014; Thiel et al., 2014; Pšidová et al., 2015; Dounavi et al., 2016). Some studies, however, found indifferent or even contradicting results (Baudis et al., 2015; Hofmann et al., 2015) after comparing populations along a smaller geographic and climatic gradient within the continuous beech range (cf. Knutzen et al., 2015). Also Wortemann et al. (2011) found no evidence for genetic differentiation across beech populations for vulnerability to embolism by comparing European populations originating from the continuous distribution range of beech, only.

The adaptive potential of European beech, and other plant organisms, to drought and other climatic extreme events is triggered by two main processes: (1) genetic variation and/or (2) phenotypic plasticity (Meier and Leuschner, 2008; Lindner et al., 2010; Aranda et al., 2015). Genetic diversity of beech is mainly shaped by its phylogeographic history during the Pleistocene and Holocene (Harter et al., 2015). The isolated location of Pleistocene refuge areas and re-colonization pathways were indicative for large-scale genetic differentiation in Central European and Mediterranean distributions (Magri et al., 2006). Isolation during the highly variable interglacial climate conditions in the Pleistocene played a major role in increasing the genetic complexity of extant refuge populations, only partly preserved during the post-Pleistocene re-colonization toward north ("southern complexity" and "northern purity" paradigm, de Lafontaine et al., 2013). However, this interferes with recent evolutionary adaptation processes at the local level, occurring over only one or a few generations (Hamrick, 2004), when extreme weather events like droughts induce directed selection processes (Aitken et al., 2008; Spathelf et al., 2015). In particular for beech, marginal populations at the xeric distribution boundary are reputed to be the focus of local adaptation to drought, reducing genetic variation of local populations (Hampe and Petit, 2005) that exist in heterogeneous environments (Pluess et al., 2016). 
The close correlation found between precipitation during the growing season (Prec. 4-9) at the population origins and the critical drought thresholds (LD50 SWA $_{\text {) }}$ of the populations (Figure 3) suggests for local adaptation brought about mainly by recent evolutionary adaptation. This would explain also the fact that the actual precipitation conditions are indicative for the drought tolerance found and not the southern origin of the population near or even in Pleistocene refuge areas. In this sense, the distribution margin of beech, and thus the location of marginal beech populations, needs to be interpreted more in an ecological sense as beech occurrence near to its xeric limits rather than geographically by southern or eastern marginal location (cf. Hampe and Petit, 2005). This would mean that "ecologically" marginal populations due to local or regional xeric conditions may also occur within the continuous distribution range.

\section{Extreme Drought Adaptation, Desiccation Tolerance, and Mortality of Beech}

Our findings underline the importance of assessing the adaptation of beech to drought at the intraspecific level. Hydraulic trait variations are seen as a major reason for different drought responses of tree populations within the species distribution range (Lamy et al., 2011; Balducci et al., 2015). Ecophysiological measurements (gas exchange, chlorophyll fluorescence) conducted alongside our drought experiment (Cocozza et al., personal communication) revealed differences in functional traits among the beech populations, but found no clear gradient in relation to location and climatic conditions at population origins. This addressed, however, mainly the drought response phase until complete stomata closure and considerable loss of hydraulic conductivity (at around $20 \%$ SWA and $\Psi_{\mathrm{PD}} \approx$ $-2 \mathrm{MPa}$, Figure 4A, cf. Hacke and Sauter, 1995; Cochard et al., 1999; Cruiziat et al., 2002). This is, however, decoupled from later desiccation and mortality dynamics (Delzon and Cochard, 2014). More than $90 \%$ loss of hydraulic conductivity of beech seedlings and young stands is reputed to be reached between $-2.2 \mathrm{MPa}$ (Magnani and Borghetti, 1995) and -4.0 MPa (Cochard et al., 1999). Advanced mortality in young beech was found at mean xylem water potentials of $-4.5 \mathrm{MPa}$ (Barigah et al., 2013, and this study). Furthermore, a recent study of mature beech in Germany revealed $88 \%$ of conductivity loss (P88) at xylem pressure means between -4.0 and $-4.5 \mathrm{MPa}$ (Schuldt et al., 2015). These findings fit well to our estimated variation of $-2.3 \mathrm{MPa}$ and nearly $-5.0 \mathrm{MPa} \Psi_{\mathrm{PD}}$ at LD50 $0_{\text {SWA }}$ when $50 \%$ mortality have occurred (Figure 4B). The outcome also strongly supports the idea of Delzon and Cochard (2014) that 50\% mortality is linked to the almost complete loss of hydraulic conductivity (P88) in angiosperm trees like beech. Thus, LD50 ${ }_{\text {SwA }}$ and P88 seem to represent corresponding indicators for lethal drought in beech and probably other angiosperms.

For plant survival under extreme drought, the ability to prolong the desiccation process and keep hydraulic integrity as long as possible seems to be a key adaptive issue (Bréda et al., 2006). In general, desiccation tolerance in plants involves the capacity to avoid deleterious effects of water shortage on the cellular membranes and maintain the bilayer structure in a xeric environment (e.g., Leprince et al., 1993). However, for taller vascular plants such as trees with complex hydraulic architecture, the resistance to cavitation and xylem embolism is by far the most important feature for desiccation tolerance (Lüttge et al., 2011). Our results suggest that there should be intra-specific variation in (1) morphological traits avoiding uncontrolled leaf water losses and/or (2) resistance to cavitation and hydraulic failure. Genetic variability in cavitation resistance is not clear for European beech, yet (Wortemann et al., 2011), but has been described in combination with morphological adaptation for Holm oak ecotypes (Quercus ilex, Peguero-Pina et al., 2014). Moreover, for beech populations significant differences in xylem anatomy (vessel size and vessel density) were found by Eilmann et al. (2014), which clearly point to higher drought resistance of a southern Bulgarian population from more xeric environments compared to those from mesic environments.

\section{CONCLUDING REMARKS}

Our study demonstrates that the introduced LD50 ${ }_{\text {SWA }}$ indicator is a feasible indicator for critical soil water availability (SWA) in relation to plant desiccation and mortality. Thus, a residual SWA of 20\% represents a critical limit (Granier et al., 2007), below which the risk of beech seedling mortality increases drastically. Also the correspondence of our LD50 ${ }_{\text {SWA }}$ indicator with the P88 indicator found to describe a lethal water status in angiosperms (Delzon and Cochard, 2014) enables novel links for coupling ecophysiological and statistical mortality assessments. These insights provide new possibilities for local and regional modeling of drought risks based on soil water balance modeling. The significant intraspecific variation in survival under extreme drought (LD50 SWA and mortality dynamics) found can be used for the pre-selection of beech populations identified as especially apt for coping with the future climate. Further testing of these populations would be needed as well as more research on how this knowledge could apply in forest management aiming to increase our forests resistance to climate change. The differences revealed between "geographically" marginal and "climatically" marginal beech populations should be a matter of further research since common ideas of adaptive marginal populations may be biased, in particular due to the varying high-altitudinal location of southern population. Further research gaps include (1) the morphological and physiological background of genetic variation of adaptation and (2) the contribution of genetic variability and phenotypic plasticity to adaptive potentials of European beech.

\section{AUTHOR CONTRIBUTIONS}

All authors (AB, TC, CC, RT, MM, EP, LubD, LucD, SD, HC, AR, $\mathrm{ML}, \mathrm{BC}, \mathrm{CH}$ and JM) contributed substantially to the writing of the manuscript. AB, TC, CC, RT, MM, EP, LubD, and JM drafted the conceptual design with the help of the author group and conducted the study. In addition, LucD, AR, ML, BC collected and delivered seed material for the study. 


\section{ACKNOWLEDGMENTS}

We are grateful to Dr. Mirko Liesebach and Rainer Ebbinghaus from the Thünen Institute of Forest Genetics (Groß-Hansdorf, Germany) for the cultivation of the beech seedlings used in this experiment. Moreover we thank Prof. Dr. Harald

\section{REFERENCES}

Aitken, S. N., Yeaman, S., and Holliday, J. A. (2008). Adaptation, migration or extirpation: climate change outcomes for tree populations. Evol. Appl. 1, 95-111. doi: 10.1111/j.1752-4571.2007.00013.x

Allen, C. D., Macalady, A. K., Chenchouni, H., Bachelet, D., McDowell, N., Vennetier, M., et al. (2010). A global overview of drought and heat-induced tree mortality reveals emerging climate change risks for forests. For. Ecol. Manage. 259, 660-684. doi: 10.1016/j.foreco.2009.09.001

Aranda, I., Cano, F. J., Gascó, A., Cochard, H., Nardini, A., Mancha, J. A., et al. (2015). Variation in photosynthetic performance and hydraulic architecture across European beech (Fagus sylvatica L.) populations supports the case for local adaptation to water stress. Tree Phys. 35, 34-46. doi: 10.1093/treephys/tpu101

Aranda, I., Gil, L., and Pardos, J. A. (2000). Water relations and gas exchange in Fagus sylvatica L. and Quercus petraea (Mattuschka) Liebl. in a mixed stand at their southern limit of distribution in Europe. Trees 14, 344-352. doi: $10.1007 /$ s004680050229

Balducci, L., Deslauriers, A., Giovannelli, A., Beaulieu, M., Delzon, S., Rossi, S., et al. (2015). How do drought and warming influence plant survival and wood traits of Picea mariana saplings? J. Exp. Bot. 66, 377-389. doi: 10.1093/jxb/eru431

Barigah, T. S., Charrier, O., Douris, M., Bonhomme, D., Herbette, S., Améglio, T., et al. (2013). Water stress-induced xylem hydraulic failure is a causal factor of tree mortality in beech and poplar. Ann. Bot. 112, 1431-1437. doi: $10.1093 / \mathrm{aob} / \mathrm{mct} 204$

Barranco, D., Ruiz, N., and Gómez-del Campo, M. (2005). Frost tolerance of eight olive cultivars. Hortscience 40, 558-560.

Baudis, M., Premper, T., Welk, E., and Bruelheide, H. (2015). The response of three Fagus sylvatica L. provenances to water availability at different soil depths. Ecol. Res. 1287, 1-13. doi: 10.1007/s11284-015-1287-x

Blume, H.-P., Brümmer, G. W., Fleige, H., Horn, R., Kandeler, E., Kögel-Knabner, I., et al. (2016). Soil Science. Berlin: Springer Heidelberg.

Bohn, U., Gollub, G., Hettwer, C. h., Neuhäuslová, Z., Raus, T.h., Schlüter, H., et al. (2004). Karte der Natürlichen Vegetation Europas/Map of the Natural Vegetation of Europe. Bonn-Bad Godesberg: CD-ROM, BfN.

Bolte, A. (2015). Auswirkungen und Anpassungsmöglichkeiten: Extremwetterlagen im Wald. Thünen Rep. 30, 171-208. doi: 10.3220/REP 1434012425000

Bolte, A., Czajkowski, T., and Kompa, T. (2007). The north-eastern distribution area of European beech - a review. Forestry 80, 413-429. doi: 10.1093/forestry/cpm028

Bréda, N., Granier, A., Barataud, F., and Moyne, C. (1995). Soil water dynamics in an oak stand: I. Soil moisture, water potentials and water uptake by roots. Plant Soil 172, 17-27. doi: 10.1007/BF00020856

Bréda, N., Huc, R., Granier, A., and Dreyer, E. (2006). Temperate forest trees and stands under severe drought: a review of ecophysiological responses, adaptation processes and long-term consequences. Ann. For. Sci. 63, 625-644. doi: $10.1051 /$ forest:2006042

Brodribb, T. J., and Cochard, H. (2009). Hydraulic failure defines the recovery and point of death in water-stressed conifers. Plant Physiol. 149, 575-584. doi: 10.1104/pp.108.129783

Cavalli-Sforza, L. (1972). Biometrie. Stuttgart: Fischer.

Chmura, D. J., and Rozkowski, R. R. (2002). Variability of beech provenances in spring and autumn phenology. Silvae Genet. 1, 123-127.

Cochard, H., Lemoine, D., and Dreyer, E. (1999). The effects of acclimation to sunlight on the xylem vulnerability to embolism in Fagus sylvatica L. Plant Cell Environ. 22, 101-108. doi: 10.1046/j.1365-3040.1999.00367.x
Schill and Dr. Bernhard Götz from the University of Sustainable Development (HNE Eberswalde) for giving the opportunity to use the greenhouse facilities. This article is based upon work from COST Action FP1106 STReESS, supported by COST (European Cooperation in Science and Technology).
Collet, C., Lanter, O., and Pardos, M. (2001). Effects of canopy opening on height and diameter growth in naturally regenerated beech seedlings. Ann. For. Sci. 58, 127-134. doi: 10.1051/forest:2001112

Coumou, D., and Rahmstorf, S. (2012). A decade of weather extremes. Nat. Clim. Chang. 2, 491-496. doi: 10.1038/nclimate1452

Cruiziat, P., Cochard, H., and Ameglio, T. (2002). Hydraulic architecture of trees: main concepts and results. Ann. For. Sci. 59, 723-752. doi: 10.1051/forest:2002060

Čufar, K., De Luis, M., Angel Saz, M., Črepinšek, Z., and Kajfež-Bogataj (2012). Temporal shifts in leaf phenology of beech (Fagus sylvatica) depend on elevation. Trees 26, 1091-1100. doi: 10.1007/s00468-0120686-7

Czajkowski, T., Ahrends, B., and Bolte, A. (2009). Critical limits of soil water availability (CL-SWA) for forest trees - an approach based on plant water status. Landbauforschung - vTI Agric. For. Res. 59, 87-94.

Czajkowski, T., and Bolte, A. (2006a). Unterschiedliche Reaktion deutscher und polnischer Herkünfte der Buche (Fagus sylvatica L.) auf Trockenheit. Allg. Forst- u. J.-Ztg. 177, 30-40 (in German with English summary).

Czajkowski, T., and Bolte, A. (2006b). Frosttoleranz deutscher und polnischer Herkünfte der Buche (Fagus sylvatica L.) und ihre Beeinflussung durch Trockenheit. Arch. Forstwes. Landsch. Ökol. 40, 119-126 (in German with English summary).

Delzon, S., and Cochard, H. (2014). Recent advances in tree hydraulics highlight the ecological significance of the hydraulic safety margin. New Phytol. 203, 355-358. doi: 10.1111/nph.12798

de Lafontaine, G., Ducousco, A., Lefèvre, S., Magnanous, E., and Petit, R. (2013). Stronger spatial genetic structure in recolonized areas than in refugia in the European beech. Mol. Ecol. 22, 4397-4412. doi: 10.1111/mec.12403

De Martonne, E. (1926). Aréisme et indice artidite. Comptes Rendus de L'Acad. Sci. 182, 1395-1398.

Domec, J.-C., King, J. S., Ward, E., Oishi, A. O., Palmroth, S., Radecki, A., et al. (2015). Conversion of natural forests to managed forest plantations decreases tree resistance to prolonged droughts. For. Eco. Manage. 355, 58-71. doi 10.1016/j.foreco.2015.04.012

Dounavi, A., Netzer, F., Celepirovic, N., Ivankovic, M., Burger, J., Figueroa, A. G., et al. (2016). Genetic and physiological differences of European beech provenances (F. sylvatica L.) exposed to drought stress. For. Ecol. Manage. 361, 226-236. doi: 10.1016/j.foreco.2015.11.014

Eilmann, B., Sterck, F., Wegner, L., de Vries, S. M., Arx, G., von, Mohren, G. M., et al. (2014). Wood structural differences between northern and southern beech provenances growing at a moderate site. Tree Physiol. 34, 882-893. doi: $10.1093 /$ treephys/tpu069

Ellenberg, H. (1988). Vegetation Ecology of Central Europe. 4th Edn. Cambridge: Cambridge Univ. Press.

Ellenberg, H., and Leuschner, C. (2010). Vegetation Mitteleuropas mit den Alpen. 6. Aufl. E. Stuttgart: Ulmer Verlag.

Emborg, J. (1998). Understorey light conditions and regeneration with respect to the structural dynamics of a near-natural deciduous forest in Denmark. For. Ecol. Manage. 106, 83-95. doi: 10.1016/S0378-1127(97)00299-5

Fang, J., and Lechovicz, M. J. (2006). Climatic limits for the present distribution of beech (Fagus L.) species in the world. J. Biogeogr. 33, 1804-1819. doi: 10.1111/j.1365-2699.2006.01533.x

García-Plazaola, J. I., and Becerril, J. M. (2000). Effects of drought on photoprotective mechanisms in European beech (Fagus sylvatica L.) seedlings from different provenances. Trees 14, 485-490. doi: 10.1007/s004680000068

Gessler, A., Keitel, C., Kreuzwieser, J., Matyssek, R., Seiler, W., and Rennenberg, H. (2007). Potential risks for European beech (Fagus sylvatica L.) in a changing climate. Trees 21, 1-11. doi: 10.1007/s00468-006-0107-x 
Granda, V., Delatorre, C., Cuesta, C., Centeno, M. L., Fernández, B., Rodríguez, A., et al. (2015). Physiological and biochemical responses to severe drought stress of nine Eucalyptus globulus clones: a multivariate approach. Tree Phys. 34, 778-786. doi: 10.1093/treephys/tpu052

Granier, A., Reichstein, M., Breda, N., Janssens, I. A., Falge, E., Ciais, P., et al. (2007). Evidence for soil water control on carbon and water dynamics in European forests during the extremely dry year 2003. Agric. For. Meteorol. 143, 123-145. doi: 10.1016/j.agrformet.2006.12.004

Gregorczyk, A. (1991). The logistic function - its application to the description and prognosis of plant growth. Acta Soc. Bot. Pol. 60, 67-76 doi: 10.5586/asbp.1991.004

Hacke, U., and Sauter, J. J. (1995). Vulnerability of xylem to embolism in relation to leaf water potential and stomatal conductance in Fagus sylvatica f. purpurea and Populus balsamifera. J. Exp Bot. 46, 1177-1183. doi: 10.1093/jxb/46.9.1177

Hampe, A., and Petit, R. J. (2005). Conserving biodiversity under climate change: the rear edge matters. Ecol. Lett. 8, 461-467. doi: 10.1111/j.14610248.2005.00739.x

Hamrick, J. L. (2004). Response of forest trees to global environmental changes. For. Ecol. Manage. 197, 323-335. doi: 10.1016/j.foreco.2004.05.023

Harter, D. E. V., Nagy, L., Backhaus, S., Beierkuhnlein, C., Fussi, B., Huber, G., et al. (2015). A comparison of genetic diversity and phenotypic plasticity among European Beech (Fagus sylvatica L.) populations from Bulgaria and Germany under drought and temperature manipulation. Int. J. Plant Sci. 176, 232-244. doi: $10.1086 / 679349$

Hofmann, M., Durka, W., Liesebach, M., and Bruelheide, H. (2015). Intraspecific variability in frost hardiness of Fagus sylvatica L. Eur. J. Forest Res. 134, 433-441. doi: $10.1007 /$ s10342-015-0862-6

IPCC (2012). "Summary for policymakers," in Managing the Risks of Extreme Events and Disasters to Advance Climate Change Adaptation, A Special Report of Working Groups I and II of the Intergovernmental Panel on Climate Change, eds C. B. Field, V. Barros, T. F. Stocker, D. Qin, D. J. Dokken, K. L. Ebi, M. D. Mastrandrea, K. J. Mach, G.-K. Plattner, S. K. Allen, M. Tignor, and P. M. Midgley (Cambridge, UK; New York, NY: Cambridge University Press), 1-19.

IPCC (2013). “Summary for policymakers," in Climate Change 2013: The Physical Science Basis. Contribution of Working Group I to the Fifth Assessment Report of the Intergovernmental Panel on Climate Change, eds T. F. Stocker, D. Qin, G.-K. Plattner, M. M. B. Tignor, S. K. Allen, J. Boschung, A. Nauels, Y. Xia, V. Bex, and P. M. Midgley (Cambridge, UK; New York, NY: Cambridge University Press), 3-32.

Ivojević, S., Višnjić, Ć., and Mekić, F. (2012). Drought-Resistance of Various Provenances of Beech (Fagus sylvatica L.) from Parts of Its Natural Range in Bosnia and Herzegovina. Works of the Faculty of Forestry, University of Sarajevo 1, 19-28.

Knutzen, F., Meier, I. C., and Leuschner, C. (2015). Does reduced precipitation trigger physiological and morphological drought adaptations in European beech (Fagus sylvatica L.)? Comparing provenances across a precipitation gradient. Tree Phys. 35, 949-963. doi: 10.1093/treephys/tpv057

Kreyling, J., Buhk, C., Backhaus, S., Hallinger, M., Huber, G., Huber, L., et al. (2014). Local adaptations to frost in marginal and central populations of the dominant forest tree Fagus sylvatica L. as affected by temperature and extreme drought in common garden experiments. Ecol. Evol. 4, 594-605. doi: 10.1002/ece3.971

Kursar, T. A., Engelbrecht, B. M. J., Burke, A., Tyree, M. T., Bouchra, E. I., Omari, B., et al. (2009). Tolerance to low leaf water status of tropical tree seedlings is related to drought performance and distribution. Funct. Ecol. 23, 93-102. doi: 10.1111/j.1365-2435.2008.01483.x

Lamy, J.-B., Bouffier, L., Burlett, R., Plomion, C., Cochard, H., and Delzon, S. (2011). Uniform selection as a primary force reducing population genetic differentiation of cavitation resistance across a species range. PLOS ONE 6:e23476. doi: 10.1371/journal.pone.0023476

Leprince, O., Hendry, G. A. F., and McKersie, B. D. (1993). The mechanisms of desiccation tolerance in developing seeds. Seed Sci. Res. 3, 231-246. doi: 10.1017/S0960258500001859

Leuschner, C., Meier, I. C., and Hertel, D. (2006). On the niche breadth of Fagus sylvatica: soil nutrient status in 50 Central European beech stands on a broad range of bedrock types. Ann. For. Sci. 63, 335-368. doi: 10.1051/forest:2006016

Lindner, M., Maroschek, M., Netherer, S., Kremer, A., Barbati, A., GarciaGonzalo, J., et al. (2010). Climate change impacts, adaptive capacity, and vulnerability of European forest ecosystems. For. Ecol. Manage. 259, 698-709. doi: 10.1016/j.foreco.2009.09.023

Lüttge, U., Beck, E., and Bartels, D. (eds.). (2011). Plant Desiccation Tolerance. Ecol. Stud. 215. Berlin; Heidelberg: Springer.

Magnani, F., and Borghetti, M. (1995). Interpretation of seasonal changes of xylem embolism and plant hydraulic resistance in Fagus sylvatica. Plant Cell Environ. 18, 689-696. doi: 10.1111/j.1365-3040.1995.tb00570.x

Magri, D., Vendramin, G. G., Comps, B., Dupanloup, I., Geburek, T., Gömöry, D., et al. (2006). A new scenario for the Quaternary history of European beech populations: paleobotanical evidence and genetic consequences. New Phytol. 171, 199-221. doi: 10.1111/j.1469-8137.2006.01740.x

Martínez del Castillo, E., Longares Aladrén, A. A., Gričar, J., Prislan, P., Pelegrín, E. G., Čufar, K., et al. (2016). Living on the edge: contrasted wood-formation dynamics in Fagus sylvatica and Pinus sylvestris under Mediterranean conditions. Front. Plant Sci. 7:370. doi: 10.3389/fpls.2016.00370

Meier, I. C., and Leuschner, C. (2008). Genotypic variation and phenotypic plasticity in the drought response of fine roots of European beech. Tree Phys. 28, 297-309. doi: 10.1093/treephys/28.2.297

Meir, P., Wood, T. E., Galbraight, D. R., Brando, P. M., Da Costa, A. C. L., Rowland, L., et al. (2015). Threshold responses to soil moisture deficit by trees and soil in tropical rain forests: insights from field experiments. Bioscience 65, 882-892. doi: 10.1093/biosci/biv107

Nielsen, C. N., and Jørgensen, F. V. (2003). Phenology and diameter increment in seedlings of European beech (Fagus sylvatica L.) as affected by different soil water contents: variation between and within provenances. For. Ecol. Manage. 174, 233-249. doi: 10.1016/S0378-1127(02)00042-7

Peguero-Pina, J. J., Sancho-Knapik, D., Barrón, E., Camarero, J. J., Vilagrosa, A., and Gil-Pelegrín, E. (2014). Morphological and physiological divergences within Quercus ilex support the existence of different ecotypes depending on climatic dryness. Ann. Bot. 114, 301-313. doi: 10.1093/aob/mcu108

Peuke, A. D., Schraml, C., Hartung, W., and Rennenberg, H. (2002). Identification of drought-sensitive beech ecotypes by physiological parameters. New Phytol. 154, 373-387. doi: 10.1046/j.1469-8137.2002.00400.x

Pluess, A. R., Frank, A., Heiri, C., Lalagüe, H., Vendramin, G. G., and OddouMuratorio, S. (2016). Genome-environment association study suggests local adaptation to climate at the regional scale in Fagus sylvatica. New. Phytol. 210, 589-601. doi: 10.1111/nph.13809

Prislan, P., Gričar, J., De Luis, M., Smith, K. T., and Čufar, K. (2013). Phenological variation in xylem and phloem formation in Fagus sylvatica from two contrasting sites. Agrar. For. Met. 180, 142-151. doi: 10.1016/j.agrformet.2013.06.001

Pšidová, E., Ditmarová, L., Jamnická, G., Kurjak, D., Majerová, J., Czajkowski, T., et al. (2015). Photosynthetic response of beech seedlings of different origin to water deficit. Photosythetica 53, 187-194. doi: 10.1007/s11099-015-0101-x

Reid, J. O., Hashim, O., and Gallagher, J. N. (1984). Relations between available and extractable soil water and evapotranspiration from a bean crop. Agric. Water Manage. 9, 193-209. doi: 10.1016/0378-3774(84)90002-7

Ritchie, J. T. (1981). Water dynamics in the soil-plant-atmosphere system. Plant Soil 58, 81-69. doi: 10.1007/BF02180050

Robson, T. M., Rasztovits, E., Aphalo, P. J., Alia, R., and Aranda, I. (2013). Flushing phenology and fitness of European beech (Fagus sylvatica L.) provenances from a trial in La Rioja, Spain, segregate according to their climate of origin. Agrar. For. Met. 180, 176-185. doi: 10.1016/j.agrformet.2013. 05.008

Rose, L., Leuschner, C., Köckemann, B., and Buschmann, H. (2009). Are marginal beech (Fagus sylvatica L.) provenances a source for drought tolerant ecotypes? Eur. J. Forest Res. 128, 335-343. doi: 10.1007/s10342-009-0268-4

SAS Institute Inc (2014). JMP ${ }^{\circledR} 11$ Consumer Research. Cary, NC: SAS Institute Inc.

Scharnweber, T., Manthey, M., Criege, C., Bauwe, A., Schröder, C., and Wilmking, M. (2011). Drought matters - Declining precipitation influences growth of Fagus sylvatica L. and Quercus robur L. in north-eastern Germany. For. Ecol. Manage. 262, 947-961. doi: 10.1016/j.foreco.2011. 05.026

Scholander, P. F., Hammel, H. T., Hemmingsen, E. A., and Bradstreet, E. D. (1964). Hydrostatic pressure and osmotic potential in leaves of mangroves and some other plants. Proc. Nat. Acad. Sci. U.S.A. 52, 119-125. doi: $10.1073 /$ pnas.52.1.119 
Schraml, C., and Rennenberg, H. (2002). Ökotypen der Buche (Fagus sylvatica L.) zeigen unterschiedliche Reaktionen auf Trockenstreß. Forstw. Cbl. 121, 59-72. doi: 10.1046/j.1439-0337.2002.00059.x

Schuldt, B., Knutzen, F., Delzon, S., Jansen, S., Müller-Haubold, H., Burlett, R., et al. (2015). How adaptable is the hydraulic system of European beech in the face of climate change-related precipitation reduction? New Phytol. doi: 10.1111/nph.13798

Spathelf, P., Bolte, A., and van der Maaten, E. (2015). Is Close-to-Nature Silviculture (CNS) an adequate concept to adapt forests to climate change? Landbauforsch. App. Agric. Forestry Res. 65, 161-170. doi: 10.3220/LBF1452526188000

Sperry, J. S., Adler, F. R., Campbell, G. S., and Comstock, J. C. (1998). Limitation of plant water use by rhizosphere and xylem conductance: results from a model. Plant Cell Environ. 21, 347-359. doi: 10.1046/j.1365-3040.1998.00287.x

Spinoni, J., Naumann, G., Vogt, J., and Barbosa, P. (2015). European drought climatologies and trends based on a multi-indicator approach. Glob. Planet. Change 127, 50-57. doi: 10.1016/j.gloplacha.2015.01.012

Stagge, J. H., Rizzi, J., Tallaksen, L. M., and Stahl, K. (2015). Future Meteorological Droughts: Projections of Regional Climate Models for Europe. DROUGHTR\&SPI Techn. Rep. 25, University Oslo, Norway (UiO) and University Freiburg, Germany (ALU-FR): 19.

Thiel, D., Kreyling, J., Backhaus, S., Beierkuhnlein, C., Buhk, C., Egen, K., et al. (2014). Different reactions of central and marginal provenances of Fagus sylvatica to experimental drought. Eur. J. Forest Res. 133, 247-260. doi: 10.1007/s10342-013-0750-x

Tognetti, R., Michelozzi, M., and Borghetti, M. (1995). The response of European beech (Fagus sylvatica L.) seedlings from two Italian populations to drought and recovery. Trees 9, 348-354. doi: 10.1007/BF00202499

Urli, M., Porté, A. J., Cochard, H., Guengant, Y., Burlett, R., and Delzon, S. (2013). Xylem embolism threshold for catastrophic hydraulic failure in angiosperm trees. Tree Phys. 33, 672-683. doi: 10.1093/treephys/tpt030
Veihmeyer, F. J., and Hendrickson, A. H. (1927). The relation of soil moisture to cultivation and plant growth. Proc. 1st Intern. Congr. Soil Sci. 3, 498-513.

Visnjic, V. C., and Dohrenbusch, A. (2004). Frost resistance and phenology of European beech provenances (Fagus sylvatica L.). Allg. Forst u. Jgdz. 175, $101-108$.

Vornam, B., Decarli, N., and Gailing, O. (2004). Spatial distribution of genetic variation in a natural beech stand (Fagus sylvatica L.) based on microsatellite markers. Cons. Genet. 5, 561-570. doi: 10.1023/B:COGE.0000041025.82917.ac

Wortemann, R., Herbette, S., Barigah, T. S., Fumanal, B., Alia, R., Ducousso, A., et al. (2011). Genotypic variability and phenotypic plasticity of cavitation resistance in Fagus sylvatica L. across Europe. Tree Phys. 31, 1175-1182. doi: 10.1093/treephys/tpr101

Wuehlisch, G., von Krusche, D., and Muhs, H.-J. (1995). Variation in temperature sum requirements for flushing of beech provenances. Silv. Genetica 44, 343-346.

Zhang, M. I. N., and Willison, J. H. M. (1987). An improved conductivity method for measurement of frost hardiness. Can. J. Bot. 65, 710-715. doi: 10.1139/b 87-095

Conflict of Interest Statement: The authors declare that the research was conducted in the absence of any commercial or financial relationships that could be construed as a potential conflict of interest.

Copyright (C) 2016 Bolte, Czajkowski, Cocozza, Tognetti, de Miguel, Pšidová, Ditmarová, Dinca, Delzon, Cochard, Rcebild, de Luis, Cvjetkovic, Heiri and Müller. This is an open-access article distributed under the terms of the Creative Commons Attribution License (CC BY). The use, distribution or reproduction in other forums is permitted, provided the original author(s) or licensor are credited and that the original publication in this journal is cited, in accordance with accepted academic practice. No use, distribution or reproduction is permitted which does not comply with these terms. 